\title{
Marinospirillum insulare sp. nov., a novel halophilic helical bacterium isolated from kusaya gravy
}

\author{
Correspondence \\ T. Fujii \\ ttfujii@s.kaiyodai.ac.jp
}

\author{
M. Satomi,† B. Kimura, M. Hayashi, M. Okuzumi and T. Fujii \\ Department of Food Science and Technology, Tokyo University of Marine Science and \\ Technology, 4-5-7 Konan, Minato-ku, Tokyo 108-8477, Japan
}

\begin{abstract}
A novel species that belongs to the genus Marinospirillum is described on the basis of phenotypic characteristics, phylogenetic analysis of $16 \mathrm{~S}$ rRNA and gyrB gene sequences and DNA-DNA hybridization. Four strains of helical, halophilic, Gram-negative, heterotrophic bacteria were isolated from kusaya gravy, which is fermented brine that is used for the production of traditional dried fish in the Izu Islands of Japan. All of the new isolates were motile by means of bipolar tuft flagella, of small cell size, coccoid-body-forming and aerophilic; it was concluded that they belong to the same bacterial species, based on DNA-DNA hybridization values ( $>70 \%$ DNA relatedness). DNA $\mathrm{G}+\mathrm{C}$ contents of the new strains were $42-43 \mathrm{~mol} \%$ and they had isoprenoid quinone $\mathrm{Q}-8$ as the major component. Phylogenetic analysis of $16 \mathrm{~S}$ rRNA gene sequences indicated that the new isolates were members of the genus Marinospirillum; sequence similarity of the new isolates to Marinospirillum minutulum, Marinospirillum megaterium and Marinospirillum alkaliphilum was $98 \cdot 5,98 \cdot 2$ and $95 \cdot 2 \%$, respectively. Phylogenetic analysis based on the gyrB gene indicated that the new isolates had enough phylogenetic distance from $M$. minutulum and $M$. megaterium to be regarded as different species, with $84 \cdot 7$ and $78 \cdot 7 \%$ sequence similarity, respectively. DNA-DNA hybridization showed that the new isolates had $<36 \%$ DNA relatedness to M. minutulum and M. megaterium, supporting the phylogenetic conclusion. Thus, a novel species is proposed: Marinospirillum insulare sp. nov. (type strain, $\mathrm{K}^{\top}=\mathrm{LMG} 21802^{\top}=\mathrm{NBRC} 100033^{\top}$ ).
\end{abstract}

Members of the genus Marinospirillum, which was established in 1998 (Satomi et al., 1998), have been isolated from putrid shellfish (Terasaki, 1972), kusaya gravy (Satomi et al., 1998) and an alkaline soda lake in China (Zhang et al., 2002); three species have so far been reported in this genus (Marinospirillum minutulum, Marinospirillum megaterium and Marinospirillum alkaliphilum). All species that belong to this genus are helical, halophilic, Gram-negative, heterotrophic and motile by means of a single polar flagellum or bipolar flagellar tuft and belong to the $\gamma$-subclass of the Proteobacteria. Almost all of their characteristics are similar to those of the genus Oceanospirillum (Hylemon et al., 1973; Krieg, 1984; Holt et al., 1994; Satomi et al., 2002), indicating

Published online ahead of print on 8 August 2003 as DOI 10.1099/ ijs.0.02768-0.

tPresent address: National Research Institute of Fisheries Science, 2-12-4 Fukuura, Kanazawa-ku, Yokohama City, Kanagawa 236-8648, Japan.

Abbreviation: $\mathrm{PHB}$, poly- $\beta$-hydroxybutyrate.

The GenBank/EMBL/DDBJ accession numbers for the 16S rRNA gene sequences generated in this study are AB098510-AB098513 and that for the gyrB sequence of strain $\mathrm{K}^{\top}$ is $\mathrm{AB098514}$.

Tables showing differential characteristics and DNA-DNA hybridization values of Marinospirillum species and a phylogenetic tree based on the gyrB gene are available as supplementary material in IJSEM Online. that it is difficult to distinguish between these genera solely on the basis of phenotype.

In previous investigations of the functions and diversity of micro-organisms in a traditional fermented brine called kusaya gravy (Fujii, 1977, 1978; Fujii et al., 1985, 1993; Satomi et al., 1997b), which is used for producing Japanese traditional dried fish, halophilic and large helical bacteria have been isolated (Satomi et al., 1998). Also, small helical bacteria that were similar to M. minutulum were isolated occasionally by using agar media (Fujii, 1978; Kosuge et al., 1978), but their biological and taxonomic features have not been investigated. In order to determine their taxonomic position, phenotypic, chemotaxonomic and phylogenetic analyses were performed.

\section{Bacterial strains and growth conditions}

Bacterial strains tested in this study are shown in Table 1. Four new strains $\left(\mathrm{K}^{\mathrm{T}}, \mathrm{P} 2, \mathrm{O} 5\right.$ and NB11) were isolated from kusaya gravy that was manufactured on different islands or at different times. Strain $\mathrm{K}^{\mathrm{T}}$ was isolated from kusaya gravy that was used on Niijima Island in 1988, strains P2 and O5 were isolated from kusaya gravy of Oshima Island in 1976 and strain NB11 was isolated from kusaya gravy of Shikine Island in 1980. Isolation and purification procedures were described previously (Fujii et al., 1990); they were 
Table 1. Strains investigated in this study and their isolation source

ATCC, American Type Culture Collection, Manassas, VA, USA; JCM, Japan Collection of Microorganisms, Saitama, Japan; LMG, BCCM/LMG Bacteria Collection, Laboratorium voor Microbiologie, University of Ghent, Ghent, Belgium; NBRC, National Institute of Technology and Evaluation, Biological Resource Center, Japan.

\begin{tabular}{|ll|}
\hline Species and strain & Source, place and year of isolation \\
\hline Marinospirillum insulare: & \\
$\mathrm{K}^{\mathrm{T}}=\mathrm{LMG} 21802^{\mathrm{T}}=\mathrm{NBRC} 100033^{\mathrm{T}}$ & Kusaya gravy, Niijima Island, 1988 \\
$\mathrm{P} 2=\mathrm{LMG} 21803=\mathrm{NBRC} 100036$ & Kusaya gravy, Oshima Island, 1976 \\
$\mathrm{O} 5=\mathrm{LMG} 21804=\mathrm{NBRC} 100035$ & Kusaya gravy, Oshima Island, 1976 \\
$\mathrm{NB} 11=\mathrm{LMG} 21805=\mathrm{NBRC} 100034$ & Kusaya gravy, Shikine Island, 1980 \\
Marinospirillum minutulum: & \\
ATCC $19193^{\mathrm{T}}=\mathrm{NBRC} 15450^{\mathrm{T}}$ & Marine shellfish, Hiroshima, 1959 \\
NB10 & Kusaya gravy, Shikine Island, 1980 \\
Marinospirillum megaterium JCM $10129^{\mathrm{T}}$ & Kusaya gravy, Niijima Island, 1988 \\
\hline
\end{tabular}

performed by using TSSY semi-solid agar, which contained the following ingredients: $1.7 \%$ trypticase peptone $(\mathrm{BBL})$, $0.3 \%$ phytone peptone (BBL), $0 \cdot 1 \%$ yeast nitrogen base (Difco), $3 \cdot 0 \% \mathrm{NaCl}$ and $0 \cdot 2 \%$ agar. All strains have been deposited in the BCCM/LMG Bacteria Collection, Laboratorium voor Microbiologie, University of Ghent, Ghent, Belgium (LMG) and the National Institute of Technology and Evaluation, Biological Resource Center, Japan (NBRC) as Marinospirillum insulare $\left(\mathrm{K}^{\mathrm{T}}=\mathrm{LMG} 21802^{\mathrm{T}}=\mathrm{NBRC}\right.$ $100033^{\mathrm{T}}, \quad \mathrm{P} 2=\mathrm{LMG} 21803=\mathrm{NBRC} 100036, \quad \mathrm{O} 5=\mathrm{LMG}$ $21804=$ NBRC 100035 and NB11 $=$ LMG $21805=$ NBRC 100034). They were maintained on a stab culture in semisolid marine broth (MB; Difco) that contained $0 \cdot 2 \%$ agar. The $\mathrm{pH}$ was adjusted to $8 \cdot 0$ with $1.0 \mathrm{M} \mathrm{NaOH}$. The culture was incubated for 3 days at $25^{\circ} \mathrm{C}$ in semi-solid MB. To obtain a large amount of cells, cells were cultured in TSSY broth or MB at 100 r.p.m. on a rotary shaker.

In taxonomic tests, M. minutulum ATCC $19193^{\mathrm{T}}$, M. minutulum NB10 and M. megaterium JCM $10129^{\mathrm{T}}$ were used as reference strains.

\section{Morphology and growth characteristics}

Cellular morphology and motility of the new isolates were observed by using phase-contrast microscopy. Their helix type was determined according to Bergey's Manual of Systematic Bacteriology (Krieg, 1984). Gram-staining was performed by using the modified Hucker method (Smibert \& Krieg, 1994). Accumulation of poly- $\beta$-hydroxybutyrate (PHB) was determined by the Sudan black staining method (Smibert \& Krieg, 1994). The new isolates were Gramnegative, rigidly helical, $\mathrm{PHB}$-accumulating and motile by means of bipolar tuft flagella. Thin-wall coccoid body formation was positive after 7 days culture in TSSY, but no spores were produced. Cell size under optimum conditions was $0 \cdot 1-0 \cdot 2 \mu \mathrm{m}$ in diameter and $2 \cdot 5-7 \cdot 5 \mu \mathrm{m}$ in length and the thin-wall coccoid body was $2 \cdot 0-2 \cdot 5 \mu \mathrm{m}$ in diameter. Colonies were entire, smooth, opaque, ivory, non-luminescent and about $1 \mathrm{~mm}$ in diameter on TSSY agar plates or marine agar 2216 (MA; Difco) plates that were incubated at $25^{\circ} \mathrm{C}$ for 6 days. The concentration range of $\mathrm{NaCl}$ that supported growth was determined in non-salt TSSY medium supplemented with $0,0 \cdot 5,1 \cdot 0,2 \cdot 0,2 \cdot 5,3 \cdot 0,4 \cdot 0,5 \cdot 0,7 \cdot 5$ or $10 \cdot 0 \%$ $(\mathrm{w} / \mathrm{v}) \mathrm{NaCl}$ for 3 weeks. All new isolates were able to grow at $0 \cdot 5-10 \% \mathrm{NaCl}$, but not at $0 \%$; optimal concentration for growth was $2-3 \%$. Temperature tolerance was tested at 0,4 , $10,15,20,25,30,37$ and $40^{\circ} \mathrm{C}$ in TSSY medium for 3 weeks. All strains were able to grow at $4-37^{\circ} \mathrm{C}$; optimum growth occurred at $25-30{ }^{\circ} \mathrm{C}$. Ability to grow at $\mathrm{pH} 6 \cdot 0-11 \cdot 0$ was tested at $0 \cdot 5$-unit increments in TSSY medium with the $\mathrm{pH}$ adjusted with $0 \cdot 1 \mathrm{M} \mathrm{NaOH}$. All cultures grew in a $\mathrm{pH}$ range of $6 \cdot 5-10 \cdot 0$, with optimum growth at $\mathrm{pH} 7 \cdot 5-8 \cdot 0$. Oxygen requirement for growth was determined by comparison of growth on TSSY plates in an anaerobic jar and under aerobic conditions. All strains tested required aerobic conditions for growth.

\section{Phenotypic characteristics}

Routine biochemical tests were carried out by using API kits (API 20NE, API ZYM and API 50CH; bioMérieux) that were prepared according to the instruction manual, except that cells were suspended in saline solution with $2.5 \% \mathrm{NaCl}$ as the final concentration. Further tests for utilization as the sole carbon source (mainly amino acids) were performed by adding energy sources $(0 \cdot 1 \%$ final concentration) to the basal medium (Baumann et al., 1972), which was solidified with noble agar (Difco). Observation of utilization tests was continued for 3 weeks. Haemolytic activity was determined on trypticase soy agar (BBL) supplemented with $2.5 \% \mathrm{NaCl}$ and $5 \%$ defibrinated sheep blood. Casein hydrolysis, production of DNase, RNase, lipase (hydrolysis of Tweens 40 or 80 ) and phenylalanine deaminase, hippurate hydrolysis and $\mathrm{O} / 129$ antibacterial susceptibility were tested as described by Smibert \& Krieg (1994). Chitin and alginate hydrolysis was tested as described by West \& Colwell (1984). 
All new isolates showed key morphological and physiological characteristics of the genus Marinospirillum, i.e. they were Gram-negative, halophilic and helical, formed coccoid bodies, were motile by means of bipolar tuft flagella, accumulated PHB, showed a positive reaction for oxidase and did not produce acid from glucose. This indicated that all new isolates were members of the genus Marinospirillum. The new isolates were able to grow at $>30^{\circ} \mathrm{C}$ and in growth media supplemented with $10 \% \mathrm{NaCl}$, reduced nitrate and had a small cell size, suggesting that they were similar to M. minutulum. The other two species of this genus have significantly different phenotypic characteristics: M. alkaliphilum is able to grow at $49^{\circ} \mathrm{C}$, is positive for urease and fails to grow in $>5 \% \mathrm{NaCl}$, whilst $M$. megaterium has a large cell size, is microaerophilic, is not able to grow at $>30{ }^{\circ} \mathrm{C}$ and does not reduce nitrate. Details of the phenotypic characteristics for the new isolates are given in Supplementary Table A in IJSEM Online.

\section{Isoprenoid quinone and fatty acid compositions}

Whole-cell lipids were extracted by using the method of Bligh \& Dyer (1959). Isoprenoid quinone type and isoprenoid length were analysed as described by AkagawaMatsushita et al. (1992). Total acetone-soluble extracts of whole-cell lipids were separated by one-dimensional chromatography on cellulose thin layers (Merck), with benzene as the eluent. Isoprenoid length was analysed by HPLC, using a reverse-phase column (Cosmosil C18; Nacalai Tesque). All new isolates contained ubiquinone that consisted mainly of Q-8. Menaquinone and methylmenaquinone were not detected. Other Marinospirillum species also have Q-8 as the major isoprenoid quinone (Satomi et al., 1998; Zhang et al., 2002). For analysis of fatty acid composition, whole-cell lipids were converted to fatty acid methyl esters by the methods given by the American Oil Chemist's Society (1990). The fatty acid methyl esters were analysed by GLC with a model GC15A chromatograph (Shimadzu) equipped with a polar capillary column (Hi-cap CBP20; Shimadzu). GLC operating conditions were described previously (Satomi et al., 1997a). The major fatty acids of all new isolates were $\mathrm{C}_{16: 0}, \mathrm{C}_{16: 1}$ and $\mathrm{C}_{18: 1}(n-7)$; this is a similar composition to that of M. minutulum.

\section{DNA preparation and DNA base composition}

Cells were collected by centrifugation from TSSY broth, suspended in TE (Tris/EDTA) buffer $(\mathrm{pH} \mathrm{8.0)}$ ) and treated with SDS (final concentration, $0 \cdot 5 \%$ ) for lysis. Chromosomal DNA was purified by standard methods (Sambrook et al., 1989). DNA base composition ( $\mathrm{G}+\mathrm{C}$ content) was determined by the HPLC method of Tamaoka \& Komagata (1984). The G + C contents of new isolates $\mathrm{K}^{\mathrm{T}}, \mathrm{P} 2, \mathrm{NB} 11$ and $\mathrm{O} 5$ were $42 \cdot 1,42 \cdot 4,42 \cdot 1$ and $42 \cdot 5 \mathrm{~mol} \%$, respectively.

\section{Phylogenetic analysis}

$16 \mathrm{~S}$ rDNA and $g y r B$ were amplified via PCR with universal primer sets that were described by Weisburg et al. (1991) and Yamamoto \& Harayama (1995), respectively, and sequenced as described previously (Satomi et al., 1997a). The GenBank/DDBJ accession numbers of the 16S rRNA gene sequences generated in this study are AB098510$\mathrm{AB} 098513$ and the $g y r B$ gene sequence of strain $\mathrm{K}^{\mathrm{T}}$ is AB098514. The $1.4 \mathrm{kbp}$ nucleotide sequences of the $16 \mathrm{~S}$ rRNA genes [covering base positions 66-1448 (Escherichia coli numbering)] and $1.1 \mathrm{kbp}$ nucleotide sequence of the gyrB gene [covering base positions 316-1472 (E. coli numbering)] were used for phylogenetic analysis. The $16 \mathrm{~S}$ rDNA sequences of the new isolates were compared with all sequence data maintained in GenBank/EMBL/DDBJ by using the BLAST algorithm (Altschul et al., 1990). Multiple alignment, calculation of nucleotide substitution rates $\left(K_{\text {nuc }}\right.$ values) as described by Kimura (1980) and construction of phylogenetic trees by the neighbour-joining method (Saitou \& Nei, 1987) were performed by using the CLUSTAL W program (Thompson et al., 1994). Alignment gaps, primer regions for PCR amplification and unidentified base positions were not taken into consideration for the calculations. The robustness of the topology of the phylogenetic trees was evaluated by bootstrap analysis over 1000 replications. 16S rRNA gene sequence similarity among the new isolates was $>99 \cdot 8 \%$ ( 2 bases difference) and three of the strains, $\mathrm{K}^{\mathrm{T}}, \mathrm{P} 2$ and NB11, had identical sequences. The phylogenetic tree that was based on the $16 \mathrm{~S}$ rRNA gene (Fig. 1) indicated that the new isolates clustered with members of the genus Marinospirillum; the closest species to the new isolates were M. minutulum and $M$. megaterium, with 98.0 and $98.2 \%$ sequence similarity, respectively. 16S rRNA gene sequence similarity between the new isolate and $M$. alkaliphilum, which has recently been reported as a novel species of this genus, was $95 \cdot 3 \%$. Generally, the threshold of sequence similarity to separate species based on the 16S rRNA gene is $97 \%$ (Stackebrandt \& Goebel, 1994), suggesting that the small phylogenetic distances of the new isolates from M. minutulum and M. megaterium do not warrant their separation as different species. On the other hand, phylogenetic analysis based on the $g y r B$ gene showed clearly that they were separated as three different species with significant sequence diversity, which was $16 \cdot 3$ and $22 \cdot 3 \%$ between the new isolates and M. minutulum and M. megaterium, respectively (see Supplementary Figure in IJSEM Online). However, threshold values to separate species based on gyrB sequence diversity are known to vary, depending on the genus. For instance, the threshold value of the genus Oceanospirillum, based on gyrB sequence diversity, was concluded to be about $20 \%$ (Satomi et al., 2002), whereas the value of the genus Shewanella was defined as $10 \%$ (Venkateswaran et al., 1999; Satomi et al., 2003). Therefore, it is necessary to confirm that the new isolates are a novel species by using genetic analysis. 


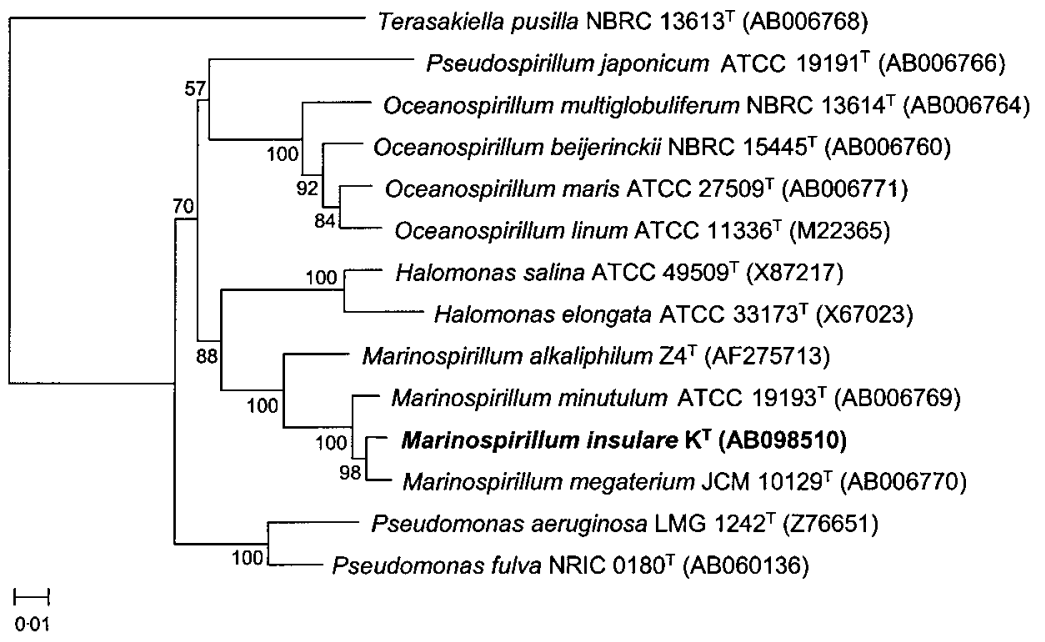

Fig. 1. Phylogenetic tree of the genus Marinospirillum based on nucleotide sequences of the 16S rRNA gene. The tree was constructed by using the neighbour-joining method and genetic distances were computed by using Kimura's model. Numbers at nodes indicate percentages of occurrence in 1000 bootstrapped trees. Terasakiella pusilla was the outgroup. GenBank accession numbers are given in parentheses; the sequence determined in this study is shown in bold type. Bar, 0.01 genetic distance.

\section{DNA-DNA hybridization}

In order to confirm the phylogenetic conclusion, DNADNA homology was studied by using microplate hybridization methods (Ezaki et al., 1989) with photobiotin labelling and colorimetric detection, as described previously (Satomi et al., 1997a). A DNA-DNA hybridization experiment revealed that the four new isolates were closely related amongst themselves (71-82 \% DNA relatedness), suggesting that they belong to the same species, but they exhibited relatively low levels of hybridization with $M$. minutulum $(31 \%)$ and $M$. megaterium (36\%) (see Supplementary Table B in IJSEM Online). This indicated strongly that the new isolates are a novel species of the genus Marinospirillum, according to the criteria for differentiation of bacterial species (Wayne et al., 1987). Genetic analysis clearly divided them as different species, although the new isolates had similar characteristics to M. minutulum.

On the basis of polyphasic studies, the four new strains from kusaya gravy were classified as a novel bacterial species of the genus Marinospirillum, Marinospirillum insulare sp. nov.

\section{Description of Marinospirillum insulare sp. nov.}

Marinospirillum insulare (in.su.la're. L. neut. adj. insulare of or belonging to an island, insular).

Gram-negative, rigidly helical, halophilic, non-sporeproducing, coccoid-body-forming, aerobic, chemoheterotrophic and PHB-accumulating bacteria. Motile by means of bipolar tufts of flagella. Cells are $0 \cdot 1-0 \cdot 2 \mu \mathrm{m}$ in diameter and $2 \cdot 5-7 \cdot 5 \mu \mathrm{m}$ in length. $\mathrm{NaCl}$ is required for growth; growth occurs at $\mathrm{NaCl}$ concentrations of $0 \cdot 5-10 \%(\mathrm{w} / \mathrm{v})$ and is optimal at $2-3 \% \mathrm{NaCl}$. Temperature range for growth is $4-37^{\circ} \mathrm{C}$; optimal temperature is $25-30^{\circ} \mathrm{C}$. pH range for growth is $6 \cdot 5-10 \cdot 0$; optimal $\mathrm{pH}$ is $8 \cdot 0$. Colonies are entire, smooth, opaque, ivory, non-luminescent and about $1 \mathrm{~mm}$ in diameter on marine agar 2216 (Difco) plates when incubated at $25{ }^{\circ} \mathrm{C}$ for 6 days. Oxidase, catalase, alkaline phosphatase and esterase are positive. Nitrate is reduced. DNase, RNase, acid phosphatase, urease, $\mathrm{N}$-acetylglucosaminase and $\beta$-galactosidase are not produced. Carbohydrates are not catabolized. Gelatin, hippurate and starch are not hydrolysed. Tolerance of $1 \%$ glycine and Oxgall is positive. $\mathrm{PHB}$, valerate and D-alanine are utilized as energy sources. Isoprenoid quinone type is Q-8. Whole-cell fatty acids consist mainly of $\mathrm{C}_{16: 0}, \mathrm{C}_{16: 1}$ and $\mathrm{C}_{18: 1}(n-7)$. DNA $\mathrm{G}+\mathrm{C}$ content is $42-43 \mathrm{~mol} \%$.

The type strain is $\mathrm{K}^{\mathrm{T}}=\mathrm{LMG} 21802^{\mathrm{T}}=\mathrm{NBRC} 100033^{\mathrm{T}}$; isolated from kusaya gravy in Japan.

\section{Acknowledgements}

The authors thank Dr Y. Terasaki for providing us with bacterial strains and for his advice on phenotypic identification and Mr T. Maeda (Marukaku-Suisan Co., Niijima Island, Japan) for providing us with the kusaya gravy samples. This study was partly supported by a Grantin-Aid from the Ministry of Education, Science and Sports and Culture of Japan (B 09460094).

\section{References}

Akagawa-Matsushita, M., Ito, T., Katayama, Y., Kuraishi, H. \& Yamasato, K. (1992). Isoprenoid quinone composition of some marine Alteromonas, Marinomonas, Deleya, Pseudomonas and Shewanella species. J Gen Microbiol 138, 2275-2281.

Altschul, S. F., Gish, W., Miller, W., Myers, E. W. \& Lipman, D. J. (1990). Basic local alignment search tool. J Mol Biol 215, 403-410.

American Oil Chemist's Society (1990). Official Methods and Recommended Practices, 4th edn. Chicago: American Oil Chemist's Society.

Baumann, L., Baumann, P., Mandel, M. \& Allen, R. D. (1972). Taxonomy of aerobic marine eubacteria. J Bacteriol 110, 402-429.

Bligh, E. G. \& Dyer, W. J. (1959). A rapid method of total lipid extraction and purification. Can J Biochem Physiol 37, 911-917.

Ezaki, T., Hashimoto, Y. \& Yabuuchi, E. (1989). Fluorometric deoxyribonucleic acid-deoxyribonucleic acid hybridization in microdilution wells as an alternative to membrane filter hybridization in 
which radioisotopes are used to determine genetic relatedness among bacterial strains. Int J Syst Bacteriol 39, 224-229.

Fujii, T. (1977). Studies on 'Kusaya'-I. Comparison of composition of 'Kusaya' brine at Niijima and Oshima islands. Nippon Suisan Gakkaishi 43, 517-521.

Fujii, T. (1978). Microbial flora of 'Kusaya' brine of Niijima and Oshima islands. Nippon Suisan Gakkaishi 44, 45-48.

Fujii, T., Sugita, H. \& Deguchi, Y. (1985). Obligately anaerobic bacteria isolated from 'Kusaya' gravy. Nippon Suisan Gakkaishi 51, 473-478.

Fujii, T., Hayashi, M. \& Okuzumi, M. (1990). New device for isolation of spiral bacteria from 'Kusaya' gravy. Nippon Suisan Gakkaishi 56, 1661.

Fujii, T., Kuda, T. \& Okuzumi, M. (1993). Anaerobic microflora of 'Kusaya' gravy. Nippon Suisan Gakkaishi 59, 185.

Holt, J. G., Krieg, N. R., Sneath, P. H. A., Staley, J. T. \& Williams, S. T. (editors) (1994). Bergey's Manual of Determinative Bacteriology, 9th edn. Baltimore: Williams \& Wilkins.

Hylemon, P. B., Wells, J. S., Jr, Krieg, N. R. \& Jannasch, H. W. (1973) The genus Spirillum: a taxonomic study. Int J Syst Bacteriol 23, 340-380.

Kimura, M. (1980). A simple method for estimating evolutionary rates of base substitutions through comparative studies of nucleotide sequences. J Mol Evol 16, 111-120.

Kosuge, T., Yokota, M., Ohba, H. \& Nagano, H. (1978). Study on kusaya-I. Antiseptic effects of kusaya brine. Nippon Suisan Gakkaishi 44, 1141-1146.

Krieg, N. R. (1984). Aerobic/microaerophilic, motile, helical/vibrioid Gram-negative bacteria. In Bergey's Manual of Systematic Bacteriology, vol. 1, pp. 71-93. Edited by N. R. Krieg \& J. G. Holt. Baltimore: Williams \& Wilkins.

Saitou, N. \& Nei, M. (1987). The neighbor-joining method: a new method for reconstructing phylogenetic trees. Mol Biol Evol 4, 406-425.

Sambrook, J., Fritsch, E. F. \& Maniatis, T. (1989). Molecular Cloning: a Laboratory Manual, 2nd edn. Cold Spring Harbor, NY: Cold Spring Harbor Laboratory.

Satomi, M., Kimura, B., Mizoi, M., Sato, T. \& Fujii, T. (1997a). Tetragenococcus muriaticus sp. nov., a new moderately halophilic lactic acid bacterium isolated from fermented squid liver sauce. Int J Syst Bacteriol 47, 832-836.

Satomi, M., Kimura, B., Takahashi, G. \& Fujii, T. (1997b). Microbial diversity of kusaya gravy. Fish Sci (Tokyo) 63, 1019-1023.

Satomi, M., Kimura, B., Hayashi, M., Shouzen, Y., Okuzumi, M. \& Fujii, T. (1998). Marinospirillum gen. nov., with descriptions of Marinospirillum megaterium sp. nov., isolated from kusaya gravy, and transfer of Oceanospirillum minutulum to Marinospirillum minutulum comb. nov. Int J Syst Bacteriol 48, 1341-1348.

Satomi, M., Kimura, B., Hamada, T., Harayama, S. \& Fujii, T. (2002). Phylogenetic study of the genus Oceanospirillum based on 16S rRNA and gyrB genes: emended description of the genus Oceanospirillum, description of Pseudospirillum gen. nov., Oceanobacter gen. nov. and Terasakiella gen. nov. and transfer of Oceanospirillum jannaschii and Pseudomonas stanieri to Marinobacterium as Marinobacterium jannaschii comb. nov. and Marinobacterium stanieri comb. nov. Int J Syst Evol Microbiol 52, 739-747.

Satomi, M., Oikawa, H. \& Yano, Y. (2003). Shewanella marinintestina sp. nov., Shewanella schlegeliana sp. nov. and Shewanella sairae sp. nov., novel eicosapentaenoic-acid-producing marine bacteria isolated from sea-animal intestines. Int J Syst Evol Microbiol 53, 491-499.

Smibert, R. M. \& Krieg, N. R. (1994). Phenotypic characterization. In Methods for General and Molecular Bacteriology, pp. 607-655. Edited by P. Gerhardt, R. G. E. Murray, W. A. Wood \& N. R. Krieg. Washington, DC: American Society for Microbiology.

Stackebrandt, E. \& Goebel, B. M. (1994). Taxonomic note: a place for DNA-DNA reassociation and 16S rRNA sequence analysis in the present species definition in bacteriology. Int J Syst Bacteriol 44, 846-849.

Tamaoka, J. \& Komagata, K. (1984). Determination of DNA base composition by reverse-phase high-performance liquid chromatography. FEMS Microbiol Lett 25, 125-128.

Terasaki, Y. (1972). Studies on the genus Spirillum Ehrenberg. I. Morphological, physiological, and biochemical characteristics of water spirilla. Bull Suzugamine Women's Coll Nat Sci 16, 1-46.

Thompson, J. D., Higgins, D. G. \& Gibson, T. J. (1994). CLUSTAL W: improving the sensitivity of progressive multiple sequence alignment through sequence weighting, position-specific gap penalties and weight matrix choice. Nucleic Acids Res 22, 4673-4680.

Venkateswaran, K., Moser, D. P., Dollhopf, M. E. \& 10 other authors (1999). Polyphasic taxonomy of the genus Shewanella and description of Shewanella oneidensis sp. nov. Int J Syst Bacteriol 49, 705-724.

Wayne, L. G., Brenner, D. J., Colwell, R. R. \& 9 other authors (1987). International Committee on Systematic Bacteriology. Report of the ad hoc committee on reconciliation of approaches to bacterial systematics. Int J Syst Bacteriol 37, 463-464.

Weisburg, W. G., Barns, S. M., Pelletier, D. A. \& Lane, D. J. (1991). $16 \mathrm{~S}$ ribosomal DNA amplification for phylogenetic study. J Bacteriol 173, 697-703.

West, P. A. \& Colwell, R. R. (1984). Identification and classification of Vibrionaceae - an overview. In Vibrios in the Environment, pp. 285-363. Edited by R. R. Colwell. New York: Wiley.

Yamamoto, S. \& Harayama, S. (1995). PCR amplification and direct sequencing of $g y r B$ genes with universal primers and their application to the detection and taxonomic analysis of Pseudomonas putida strains. Appl Environ Microbiol 61, 1104-1109.

Zhang, W., Xue, Y., Ma, Y., Grant, W. D., Ventosa, A. \& Zhou, P. (2002). Marinospirillum alkaliphilum sp. nov., a new alkaliphilic helical bacterium from Haoji soda lake in Inner Mongolia Autonomous Region of China. Extremophiles 6, 33-37. 